\title{
Kelch-Like Protein 6
}

National Cancer Institute

\section{Source}

National Cancer Institute. Kelch-Like Protein 6. NCI Thesaurus. Code C99604.

Kelch-like protein 6 ( $621 \mathrm{aa}, \sim 70 \mathrm{kDa}$ ) is encoded by the human KLHL6 gene. This protein may be involved in B-cell activation. 